\title{
VISUOMENĖS SVEIKATOS PRIEŽIŪROS PASLAUGŲ PRIEINAMUMAS DVIEJOSE SAVIVALDYBĖSE
}

\author{
Agnẻ Pačekaitė \\ Mykolo Romerio universiteto, Politikos ir vadybos fakulteto \\ Politikos mokslų institutas \\ Valakupių g. 5, LT-10101 Vilnius, Lietuva \\ Elektroninis paštas pacekaite@gmail.com
}

\section{Gintarè Petronytė}

Mykolo Romerio universiteto, Politikos ir vadybos fakulteto

Politikos mokslų institutas

Valakupių g. 5, LT-10101 Vilnius, Lietuva

Elektroninis paštas ginpetr@mruni.eu

Pateikta 2014 m. rugsejjo 4 d., parengta spausdinti 2014 m. spalio 6 d.

$$
\text { doi:10.13165/SPV-14-2-7-04 }
$$

\section{Santrauka}

Straipsnyje analizuojamas visuomenès sveikatos priežiūros paslaugų prieinamumas vyresnio amžiaus gyventojams savivaldybejje, kurioje įsteigtas visuomenès sveikatos biuras, lyginant su savivaldybe, kurioje sudaryta bendradarbiavimo sutartis dèl visuomenés sveikatos priežiūros paslaugu teikimo. 2013 m. rugpjūčiospalio men. atliktame tyrime dalyvavo 178 Anykščiu rajono ir 165 Ignalinos rajono savivaldybès $60 \mathrm{~m}$. ir vyresnio amžiaus gyventojai (toliau - vyresnio amžiaus gyventojai). Tyrimo duomenimis, Anykščiu rajono savivaldybès vyresnio amžiaus gyventojai lyginant su Ignalinos rečiau naudojosi visuomenès sveikatos priežiūros paslaugomis per pastaruosius metus. Naudojimasis analizuotomis visuomenès sveikatos priežiüros paslaugomis tarp savivaldybiu nesiskyrè, tačiau konsultacinès paslaugos sveikatos stiprinimo ir išsaugojimo klausimais dažniau buvo teikiamos Anykščiu nei Ignalinos rajono savivaldybès vyresnio amžiaus gyventojams. Abieju savivaldybiu vyresnio amžiaus gyventojams trūko paslaugu ligu profilaktikos ir sveikatos stiprinimo srityse. Ignalinos rajono savivaldybeje visuomenés sveikatos priežiūros paslaugu prieinamumas buvo geras, tuo tarpu Anykščiu rajono savivaldybès gyventoju visuomenès sveikatos priežiūros paslaugu prieinamumą ribojo komunikacinès ir organizacinès kliūtys. Abiejų savivaldybiu vyresnio amžiaus gy- 
ventojai naudodamiesi visuomenès sveikatos paslaugomis susidüré su finansiniais sunkumais dèl transporto išlaidų ir visuomenès sveikatos priežiūros paslaugų stoka.

Reikšminiai žodžiai: visuomenès sveikatos priežiūra, visuomenès sveikatos priežiūros paslaugos, visuomenès sveikatos priežiūros paslaugu prieinamumas, visuomenès sveikatos biuras.

\section{Ivadas}

Lietuvos Respublikos Vyriausybei patvirtinus nacionalinę visuomenès sveikatos priežiūros 2006-2013 m. strategiją ir jos iggyvendinimo 2009-2013 m. planą visuomenès sveikatos priežiūros plètra savivaldybėse tapo viena iš strateginių vykdomos visuomenès sveikatos priežiūros reformos krypčių ${ }^{1}$ Ittvirtinant visuomenès sveikatos priežiūros prioritetą savivaldybių iggyvendinamoje politikoje, $2007 \mathrm{~m}$. buvo priimti Visuomenès sveikatos priežiūros įstatymo pakeitimai nustatant, kad nuo $2008 \mathrm{~m}$. sausio $1 \mathrm{~d}$. visuomenès sveikatos priežiūros funkcijoms vykdyti savivaldybès steigia visuomenès sveikatos priežiūros biudžetines ístaigas - savivaldybių visuomenès sveikatos biurus, kuriems suteikta teisė sudaryti bendradarbiavimo sutartis dèl visuomenès sveikatos priežiūros paslaugų teikimo kitų savivaldybių gyventojams². Visuomenės sveikatos biurų pagrindinès veiklos sritys reglamentuotos patvirtintuose savivaldybės visuomenès sveikatos biuro pavyzdiniuose nuostatuose ${ }^{3}$, tačiau vykdoma visuomenés sveikatos priežiūros veikla įvairialype ir jos organizavimas priklauso nuo vietos valdžios institucijų priimtų sprendimų, žmogiškųjų, finansinių išteklių bei gyventojų aktyvaus dalyvavimo. Visuomenés sveikatos biurų veikla tapo orientuota į vietos bendruomenès sveikatos problemų nustatymą ir jų sprendimą, bendradarbiaujant su vietos valdžios ir nevyriausybinèmis institucijomis.

Daugelyje Europos Sąjungos šalių gyventojų senejjimas kelia ịvairių sektorių politikų susirūpinimą bei iššūkius sveikatos apsaugos sistemoms ${ }^{4,5}$. Progno-

Lietuvos Respublikos Vyriausybès 2009 m. vasario 18 d. nutarimas Nr. 111 „Dèl Lietuvos nacionalinès visuomenès sveikatos priežiūros 2006-2013 m. strategijos igyvendinimo priemonių 2009-2013 m. plano patvirtinimo“. Valstybès žinios. 2009, Nr. 22-854.

2 Ščeponavičius, A.; Ašoklienė, L.; Kavaliūnas A. Visuomenès sveikatos priežiūros plètra savivaldybėse. Nacionalinès sveikatos tarybos metinis pranešimas. 2010, p. 65-69.

3 Lietuvos Respublikos sveikatos apsaugos ministro 2008 m. kovo 15 d. įsakymas Nr. V-196 „Dèl savivaldybès visuomenès sveikatos biuro pavyzdinių nuostatų patvirtinimo“. Valstybès žinios. 2008, Nr. 35-1253.

4 Communication from the Commission to the Council, the the European Parliament, the Economic and Social Committee and the Committee of the Regions of 5 December 2001- The future of health care and care systems for the elderly: guaranteeing accessibility, quality and financial viability. COM/2001/0723.

5 Decision No 940/2011/EU of the European Parliament and the Council of 14 September 2011 on the European Year for Active Ageing and Solidarity between Generations (2012). Official Journal of the European Union. 2011, L246/5. 
zuojama, kad viešosios išlaidos sveikatos priežiūrai Europos Sąjungoje iki 2060 m. išaugs 1,5 procentinio punkto BVP. Viena iš būsimų išlaidų mažinimo priemone laikoma gyventojų sveikesnis gyvenimo būdas, todèl sveikatos stiprinimo veiksmai prisidètų prie šalių gyventojų ilgesnio bei kokybiško gyvenimo ${ }^{6}$.

Remiantis Europos Sąjungos statistikos tarnybos (Eurostato) prognozėmis, numatomas spartus Lietuvos gyventojų senejimas, todèl $2060 \mathrm{~m}$. pradžioje beveik 37 proc. Lietuvos gyventojų bus pagyvenę žmonès, o Europos Sąjungoje (27 valstybių narių vidurkis) - 35 proc. $^{7}$ Demografinio senejjimo pokyčiai lemia visuomenès sveikatos priežiūros paslaugų, orientuotų ì vyresnio amžiaus gyventojų sveikatos problemas, poreikio didejimą. Šių paslaugų teikimas ir sveiko senejjimo politikos igyvendinimas savivaldybių lygiu tampa visuomenès sveikatos biurų veiklos sritimi ${ }^{8}$. Tačiau visuomenès sveikatos priežiūros paslaugų teikimas vyresnio amžiaus gyventojams mažai analizuotas ${ }^{9}$, todèl šių paslaugų prieinamumo vertinimas tampa savalaikis, siekiant suteikti naudingą informaciją sveikatos politikams, sprendimų prièmejjams ir suinteresuotoms institucijoms, dalyvaujančioms planuojant ir igyvendinant visuomenès sveikatos priežiūrą savivaldybėse. Šio straipsnio tikslas - ịvertinti visuomenès sveikatos priežiūros paslaugų prieinamumą $60 \mathrm{~m}$. ir vyresnio amžiaus gyventojams Ignalinos ir Anykščių rajonų savivaldybèse.

\section{Tyrimo medžiaga ir metodai}

Kiekybinis tyrimas, taikant anketinès apklausos metodą, atliktas Anykščiu ir Ignalinos rajonų savivaldybėse, atsižvelgiant, kad 2013 m. 60 m. ir vyresnio amžiaus žmonès jose sudarè didelę savivaldybiu gyventojų dalị, be to, palyginti su visais šalies gyventojais šiose savivaldybėse gyveno daugiausiai šio amžiaus

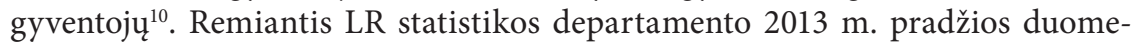
nimis, Anykščių rajono savivaldybeje gyveno 8609 - $60 \mathrm{~m}$. ir vyresnio amžiaus gyventojai (31,33 proc. visų savivaldybės gyventojų), o Ignalinos rajono savival-

6 Communication from the Commission to the European Parliament, The Council, The European Economic and Social Committee of the Regions - Dealing with the impact of an ageing population in the EU (2009 ageing raport). COM/2009/180.

7 Lietuvos Respublikos socialinès apsaugos ir darbo ministro $2012 \mathrm{~m}$. kovo $15 \mathrm{~d}$. ịsakymas Nr. A1156 „Dèl nacionalinès 2012-ụjų Europos vyresnio amžiaus žmonių aktyvumo ir kartų solidarumo metų programos patvirtinimo“. Valstybès žinios. 2012, Nr. 34-1678.

8 Tarvydienė, N.; Pačiauskienè, I. Visuomenès sveikatos biurų veikla, patirtis, užtikrinant sveiką senejjimą. Nacionalinès sveikatos tarybos metinis pranešimas. 2012, p. 84-86.

9 Sveikatos mokymo ir ligų prevencijos centras. Visuomenès sveikatos priežiūros paslaugų prieinamumo savivaldybèse vertinimas [interaktyvus]. Vilnius, 2012 [žiūrèta 2014-06-25]. <http:// www.smlpc.lt/media/file/Programos_projektai/Tarptautiniai_projektai/1.2.2/IV\%20dalis.pdf>.

10 Lietuvos statistikos departamentas [interaktyvus]. Gyventojų skaičius metų pražioje. Požymiai: administracinè teritorija, amžius, lytis [žiūrèta 2013-06-04]. <http://db1.stat.gov.lt/statbank/SelectVarVal/Define.asp?Maintable $=$ M3010202\&PLanguage $=0>$. 
dybejje - 5774 šio amžiaus gyventojai (32,87 proc. visų savivaldybės gyventojų) $)^{11}$, apskaičiuotos reprezentatyvios imtys (patikimumo lygmuo 95 proc., pasikliautinis intervalas \pm 7 proc. $)^{12}$. Tyrime, taikant atsitiktinės atrankos principą, dalyvavo 178 Anykščiu rajono savivaldybès vyresnio amžiaus gyventojai, kuriems buvo $60-81 \mathrm{~m}$. (amžiaus vidurkis 67,11 $\pm 5,709$ ) ir 165 Ignalinos rajono savival-

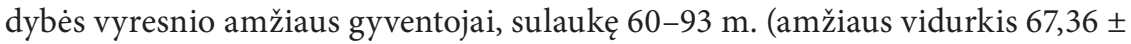
$6,694)$. Tyrime dalyvavusių vyresnio amžiaus gyventojų demografinès ir socialinės charakteristikos pateikiamos 1 lentelejje. Statistiškai reikšmingų skirtumų tarp Anykščių ir Ignalinos rajonų savivaldybių pagal lytị, amžių, išsilavinimą, vidutines pajamas, tenkančias vienam šeimos nariui per ménesị, nenustatyta. Atsako dažnis Anykščių rajono savivaldybejje - 92,71 proc., o Ignalinos rajono savivaldybeje - 86,84 proc.

Tyrimas atliktas griežtai struktūrizuoto interviu metu, taikant autorių parengtą ir žvalgomojo tyrimo metu išbandytą klausimyną. Visuomenès sveikatos priežiūros paslaugų prieinamumas gyventojų požiūriu vertintas šiose srityse: gyventojų naudojimasis teikiamomis visuomenès sveikatos paslaugomis, šių paslaugu komunikacinis, organizacinis ir ekonominis prieinamumas bei kliūtys kylančios naudojantis visuomenès sveikatos paslaugomis. Visuomenės sveikatos priežiūros paslaugų prieinamumas vertintas dviejose savivaldybėse: Anykščių rajono savivaldybeje, kurioje savivaldybès tarybos $2012 \mathrm{~m}$. gruodžio $20 \mathrm{~d}$. sprendimu Nr. TS-404 buvo sudaryta bendradarbiavimo sutartis dèl visuomenès sveikatos priežiūros paslaugų teikimo su Ignalinos rajono savivaldybe ${ }^{13}$, kurioje šios savivaldybès tarybos $2008 \mathrm{~m}$. vasario $14 \mathrm{~d}$. sprendimu Nr. T-224 buvo įsteigtas visuomenès sveikatos biuras ${ }^{14}$.

Duomenų analizei naudotas SPSS for Windows statistinis paketas (20 versija). Taikyta aprašomoji statistika: atvejų dažniai (procentai), vidurkiai ir standartiniai nuokrypiai (SN) Statistiniai požymių ryšiai vertinti taikant chi kvadrato ( $\chi 2)$ kriterijų. Pasirinktas statistinio reikšmingumo lygmuo $\mathrm{p}<0,05$.

\section{Ibid}

12 Creative Research Systems [interaktyvus]. [žiūrèta 2013-06-04]. <http://www.surveysystem.com/ sscalc.htm>.

13 Anykščių rajono savivaldybès tarybos 2012 m. gruodžio 20 d. sprendimas Nr. TS-404 „Dèl pritarimo bendradarbiavimo sutarčiai dẻl visuomenès sveikatos priežiūros paslaugų teikimo Anykščių rajono savivaldybejje“ [interaktyvus]. [žiūrèta 2014-07-25]. <http://denver.infolex.lt/anyksciai/ Default. aspx? $\mathrm{Id}=3 \&$ DocId $=5246>$.

14 Ignalinos rajono savivaldybès $2008 \mathrm{~m}$. vasario $14 \mathrm{~d}$. sprendimas Nr. T-224 „Dèl Ignalinos rajono savivaldybès visuomenès sveikatos biuro įsteigimo ir jo nuostatu patvirtinimo" [interaktyvus]. [žiūrèta 2014-07-25]. <http://195.182.92.232/vaktai/Default.aspx?Id=3\&DocId=10280>. 
1 lentelè. Vyresnio amžiaus gyventojų, dalyvavusių tyrime, demografinès ir socialinès charakteristikos

\begin{tabular}{|c|c|c|}
\hline & $\begin{array}{l}\text { Anykščių rajono } \\
\text { savivaldybe } \\
\text { (proc./n) n }=178\end{array}$ & $\begin{array}{l}\text { Ignalinos rajono } \\
\text { savivaldybe் } \\
\text { (proc./n) n }=165\end{array}$ \\
\hline \multicolumn{3}{|l|}{ Lytis } \\
\hline Vyrai & $29,8(53)$ & $31,5(52)$ \\
\hline Moterys & $70,2(125)$ & $68,5(113)$ \\
\hline \multicolumn{3}{|l|}{ Išsilavinimas } \\
\hline Aukštasis universitetinis & $5,6(10)$ & $8,5(14)$ \\
\hline Aukštesnysis & $5,6(10)$ & $11,5(19)$ \\
\hline Vidurinis ir žemesnis & $88,8(158)$ & $80,0(132)$ \\
\hline \multicolumn{3}{|l|}{ Šeiminè padètis } \\
\hline $\begin{array}{l}\text { Vedęs/ištekèjusi arba gyvena } \\
\text { nesusituokęs/-usi }\end{array}$ & $41,6(74)$ & $62,4(103)$ \\
\hline Nevedęs/netekejjusi & $9,6(17)$ & $6,7(11)$ \\
\hline Išsiskyręs/-usi & $20,2(36)$ & $8,5(14)$ \\
\hline Našlys/-è & $28,7(51)$ & $22,4(37)$ \\
\hline \multicolumn{3}{|c|}{ Vidutinès pajamos vienam šeimos nariui per mènesị } \\
\hline iki $400 \mathrm{Lt}$ & $26,4(47)$ & $13,0(21)$ \\
\hline $401-800 \mathrm{Lt}$ & $51,7(92)$ & $57,1(92)$ \\
\hline $801-1600 \mathrm{Lt}$ & $21,9(39)$ & $29,8(48)$ \\
\hline \multicolumn{3}{|l|}{ Gyvenamoji vieta } \\
\hline Miestas & $20,2(36)$ & $36,4(60)$ \\
\hline Kaimas & $79,8(142)$ & $63,6(105)$ \\
\hline
\end{tabular}

\section{Tyrimo rezultatai}

\section{Vyresnio amžiaus gyventojų naudojimasis visuomenès sveikatos priežiūros paslaugomis ir jų vertinimas}

Tyrimo duomenimis, beveik pusė (41,8 proc., $\mathrm{n}=64)$ Anykščių ir Ignalinos rajonų savivaldybių vyresnio amžiaus gyventojų visuomenès sveikatos priežiūros paslaugomis naudojosi kartą per metus, penktadalis $(21,6$ proc., $\mathrm{n}=33)$ - kartą per ketvirtí, 16,3 proc. $(n=25)$ - kartą per pusmeti, 14,4 proc. $(n=22)$ - kartą per mènesį, o 2,6 proc. $(\mathrm{n}=4)$ - kelis kartus per mėnesį. Statistiškai reikšmin- 
gų skirtumų tarp Anykščių ir Ignalinos rajonų savivaldybių vyresnio amžiaus gyventojų naudojimosi visuomenès sveikatos priežiūros paslaugomis dažnio nenustatyta.

Vertinant vyresnio amžiaus gyventojų naudojimąsi visuomenès sveikatos priežiūros paslaugomis per pastaruosius metus (12 mèn.), nustatyti statistiškai reikšmingi naudojimosi jomis skirtumai tarp Anykščių ir Ignalinos rajonų savivaldybių $\left({ }_{x}{ }^{2}=11,208,11 s=1, p=0,001\right) .36,0$ proc. $(\mathrm{n}=64)$ Anykščių ir 53,9 proc. $(n=89)$ Ignalinos rajonų savivaldybių vyresnio amžiaus gyventojų naudojosi visuomenès sveikatos paslaugomis per pastaruosius metus (12 mèn.), atitinkamai nesinaudojo - 64,0 proc. $(\mathrm{n}=114)$ Anykščiu ir 46,1 proc. $(\mathrm{n}=76)$ Ignalinos rajonų savivaldybių vyresnio amžiaus gyventojų.

Statistiškai reikšmingų naudojimosi analizuotų visuomenès sveikatos priežiūros paslaugų skirtumų tarp Anykščių ir Ignalinos rajonų savivaldybių vyresnio amžiaus gyventojų nenustatyta, išskyrus konsultacines paslaugas sveikatos stiprinimo ir išsaugojimo klausimais (2 lentelè). Konsultacinès paslaugos sveikatos stiprinimo ir išsaugojimo klausimais dažniau suteiktos Anykščiu (37,5 proc., $\mathrm{n}=24$ ) nei Ignalinos rajono savivaldybès vyresnio amžiaus gyventojams $(15,7$ proc., $\mathrm{n}=14)(\mathrm{p}=0,002)$. Tyrimo duomenimis, Anykščių ir Ignalinos rajonų savivaldybių vyresnio amžiaus gyventojai dažniausiai naudojosi profilaktinių sveikatos tikrinimų paslaugomis $(58,8$ proc., $\mathrm{n}=90)$, informacijos apie sveikatą ir jos stiprinimą teikimo paslaugomis $(38,6$ proc., $n=59)$ ir dalyvavo prevencinèse programose (35,9 proc., $\mathrm{n}=55)$, rečiausiai jie dalyvavo gyvensenos ir/ar elgesio keitimo intervencijose $(8,5$ proc., $\mathrm{n}=13)$, naudojosi imunoprofilaktikos paslaugomis $(17,0$ proc., $n=26)$ ir dalyvavo mokymuose sveikatos stiprinimo ir išsaugojimo klausimais $(20,3$ proc., $\mathrm{n}=31)$.

2 lentelè. Vyresnio amžiaus gyventojų naudojimasis visuomenès sveikatos priežiūros paslaugomis pastaruosius metus (12 mèn.) Anykščių ir Ignalinos rajonų savivaldybėse

\begin{tabular}{|l|c|c|c|}
\hline Visuomenès sveikatos priežiūros paslaugos & $\begin{array}{c}\text { Anykščiu } \\
\text { rajono } \\
\text { savivaldybė } \\
(\mathrm{n}=64)\end{array}$ & $\begin{array}{c}\text { Ignalinos } \\
\text { rajono } \\
\text { savivaldybe } \\
\text { (n=89) }\end{array}$ & $\mathrm{p}$ \\
\hline proc. (n) & proc. (n) & \\
\hline Dalyvavo prevencineje (-se) programoje (-se) & $40,6(26)$ & $32,6(29)$ & 0,307 \\
\hline Naudojosi imunoprofilaktikos paslaugomis & $12,5(8)$ & $20,2(18)$ & 0,209 \\
\hline Profilaktiškai tikrinosi sveikatą & $59,4(38)$ & $58,4(52)$ & 0,906 \\
\hline $\begin{array}{l}\text { Buvo suteikta informacija apie sveikatą ir jos } \\
\text { stiprinimą }\end{array}$ & $34,4(22)$ & $41,6(37)$ & 0,367 \\
\hline
\end{tabular}




\begin{tabular}{|l|l|l|l|}
\hline $\begin{array}{l}\text { Buvo suteikta konsultacija (-os) sveikatos } \\
\text { stiprinimo ir išsaugojimo klausimais }\end{array}$ & $37,5(24)$ & $15,7(14)$ & 0,002 \\
\hline $\begin{array}{l}\text { Dalyvavo mokymuose sveikatos stiprinimo } \\
\text { ir išsaugojimo klausimais }\end{array}$ & $21,9(14)$ & $19,1(17)$ & 0,674 \\
\hline $\begin{array}{l}\text { Dalyvavo sveikos gyvensenos ịgūdžių for- } \\
\text { mavimo renginiuose }\end{array}$ & $25,0(16)$ & $20,2(18)$ & 0,483 \\
\hline $\begin{array}{l}\text { Dalyvavo gyvensenos ir/ar elgesio keitimo } \\
\text { intervencijoje (-se) }\end{array}$ & $12,5(8)$ & $5,6(5)$ & 0,132 \\
\hline
\end{tabular}

p - lyginant Anykščių rajono savivaldybès duomenis su Ignalinos rajono savivaldybe

Dauguma (83,7 proc., $\mathrm{n}=128)$ Anykščių ir Ignalinos vyresnio amžiaus gyventoju pagrindiniu visuomenès sveikatos priežiūros paslaugų teikejju ịvardino šeimos gydytoją, o trečdalis $(32,7$ proc., $\mathrm{n}=50)$ - visuomenès sveikatos biuro specialistą. Visuomenès sveikatos priežiūros paslaugas Anykščių ir Ignalinos rajonų savivaldybių vyresnio amžiaus gyventojams rečiau teikè psichologas, socialinis darbuotojas $(4,6$ proc., $\mathrm{n}=7$ ) ar nevyriausybinių organizacijų darbuotojas savanoris (5,9 proc., $\mathrm{n}=9)$.

Anykščių ir Ignalinos rajonų savivaldybių vyresnio amžiaus gyventojai remdamiesi asmenine patirtimi vertino gautas visuomenès sveikatos priežiūros paslaugas per pastaruosius metus (12 mèn.). Tyrimo duomenimis, 19,4 proc. $(\mathrm{n}=12)$ Anykščių ir 41,6 proc. $(n=37)$ Ignalinos rajono savivaldybės vyresnio amžiaus gyventojų teigiamai (l. gerai ir gerai) vertino suteiktas visuomenès sveikatos priežiūros paslaugas, dauguma $(79,0$ proc., $\mathrm{n}=49)$ Anykščiu ir apie pusė $(53,9$ proc., $\mathrm{n}=49$ ) Ignalinos rajono savivaldybès vyresnio amžiaus gyventoju - patenkinamai. Maža dalis Anykščių (1,6 proc. $(\mathrm{n}=1)$ ir Ignalinos $(4,5$ proc., $\mathrm{n}=4)$ rajonų savivaldybių vyresnio amžiaus gyventojų neturejjo nuomonès apie suteiktas visuomenès sveikatos priežiūros paslaugas.

\section{Visuomenès sveikatos priežiūros paslaugų prieinamumas ir jo kliūtys}

Tyrime buvo analizuojamas Anykščių ir Ignalinos rajonų savivaldybių vyresnio amžiaus gyventojų visuomenès sveikatos priežiūros paslaugų prieinamumas komunikaciniu, organizaciniu ir ekonominiu aspektais. Tyrimo duomenimis, Anykščių rajono savivaldybès vyresnio amžiaus gyventojams vidutinis atstumas iki visuomenès sveikatos priežiūros paslaugų teikimo vietos - 11,62 $\mathrm{km}$, o Ignalinos rajono savivaldybès gyventojams $-7,846 \mathrm{~km}$. Vertinant laiką, sugaištą atvykimui iki visuomenès sveikatos priežiūros paslaugų teikimo vietos, nustatyti statistiškai reikšmingi skirtumai tarp Anykščių ir Ignalinos rajonų savivaldybių vyresnio amžiaus gyventojų $\left(\mathrm{x}^{2}=10,642,11 \mathrm{~s}=2, \mathrm{p}=0,005\right)$. Apie 
trečdalis (28,1 proc., $\mathrm{n}=18$ ) Anykščių ir apie pusė (53,9 proc., $\mathrm{n}=48$ ) Ignalinos rajono savivaldybių vyresnio amžiaus gyventojų teigé, kad atvykimui sugaišta iki 30 min. Anykščių rajono savivaldybès vyresnio amžiaus gyventojai dažniau nei Ignalinos atvykimui iki visuomenès sveikatos priežiūros paslaugų teikimo vietos sugaišdavo iki 60 minučių (43,8 proc., $\mathrm{n}=28)$ ir daugiau kaip 1 valandą $(28,1$ proc., $n=18)$, atitinkamai Ignalinos rajono savivaldybeje $-31,5$ proc. $(\mathrm{n}=28)$ ir 14,6 proc. $(\mathrm{n}=13)$.

Vertinant ekonominị visuomenès sveikatos priežiūros paslaugų prieinamumą nustatyta, kad daugiau Anykščių (70,3 proc., $\mathrm{n}=45)$ nei Ignalinos (47,2 proc., $\mathrm{n}=42$ ) rajono savivaldybès vyresnio amžiaus gyventojų teigè, kad naudojimasis visuomenès sveikatos priežiūros paslaugomis per pastaruosius metus (12 mèn.) jiems sukèlè papildomų išlaidų $\left(\mathrm{x}^{2}=8,114,11 \mathrm{~s}=1, \mathrm{p}=0,004\right)$. Apie trečdalis (29,7 proc., $\mathrm{n}=19)$ Anykščių ir apie puse (52,8 proc., $\mathrm{n}=47)$ Ignalinos rajono savivaldybès vyresnio amžiaus gyventojų teigè, kad naudodamiesi visuomenès sveikatos priežiūros paslaugomis jie neturejo papildomų išlaidų. Anykščių ir Ignalinos rajonų savivaldybių vyresnio amžiaus gyventojai, naudodamiesi visuomenès sveikatos priežiūros paslaugomis, finansinių sunkumų dažniausiai patyrè dèl transporto išlaidų ( 97,7 proc., $\mathrm{n}=85)$, likę $(2,3$ proc., $\mathrm{n}=2)$ - neįvardino priežasčių.

Anykščių ir Ignalinos rajonų savivaldybių vyresnio amžiaus gyventojai vertino visuomenès sveikatos priežiūros paslaugų prieinamumo aspektus. Kai kurie komunikacinio (nuvykimas iki visuomenès sveikatos priežiūros paslaugų teikimo vietos ir atstumas iki jos) ir organizacinio (informacijos sklaida) visuomenès sveikatos priežiūros paslaugų prieinamumo vertinimai tarp Anykščiu ir Ignalinos rajonų savivaldybių vyresnio amžiaus gyventojų nesiskyrè (1 pav.). Tyrimo duomenimis, Anykščių rajono savivaldybės vyresnio amžiaus gyventojai lyginant su Ignalinos rajono prasčiau vertino visuomenès sveikatos priežiūros paslaugų teikimo laiką (atitinkamai vidurkiai 3,00 ir 3,36) ir visuomenès sveikatos priežiūros paslaugų ịvairovę vyresnio amžiaus gyventojams (atitinkamai vidurkiai 2,93 ir 3,07).

Tyrime buvo analizuojamos vyresnio amžiaus gyventojų nesinaudojimo visuomenès sveikatos priežiūros paslaugomis priežastys. Anykščių ir Ignalinos rajonų savivaldybių vyresnio amžiaus gyventojai, nesinaudoję visuomenès sveikatos priežiūros paslaugomis per pastaruosius metus (12 mèn.), pagrindinèmis nesinaudojimo jomis priežastimis ịvardijo informacijos apie visuomenès sveikatos priežiūros paslaugas trūkumą $(46,3$ proc., $\mathrm{n}=88)$ ir prastą susisiekimą su visuomenès sveikatos priežiūros paslaugų teikimo vieta $(43,2$ proc., $\mathrm{n}=82)$ (2 pav.). Daugiau Anykščių rajono savivaldybès vyresnio amžiaus gyventojų $(53,5$ proc., $\mathrm{n}=61)$ lyginant su Ignalinos $(35,5$ proc., $\mathrm{n}=27)$ teigé, kad nesinaudojo visuomenès sveikatos priežiūros paslaugomis dèl informacijos apie visuomenès sveikatos priežiūros paslaugas trūkumo $\left(\mathrm{x}^{2}=5,930,1 \mathrm{~s}=1, \mathrm{p}=0,015\right)$. 


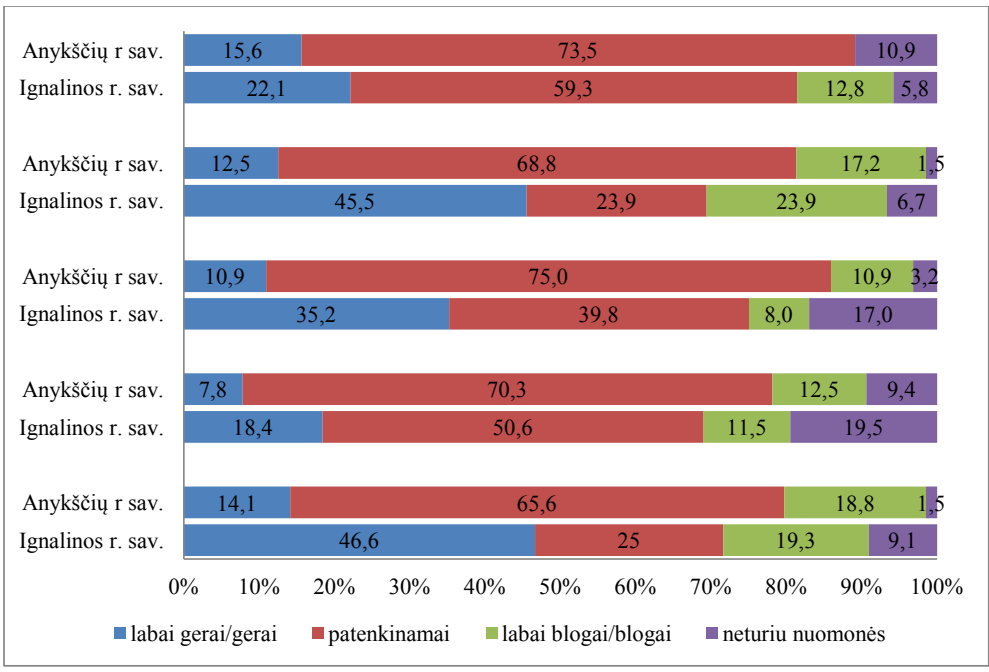

1 pav. Visuomenès sveikatos priežiūros paslaugų prieinamumo vertinimas Anykščių ir Ignalinos rajonų savivaldybėse

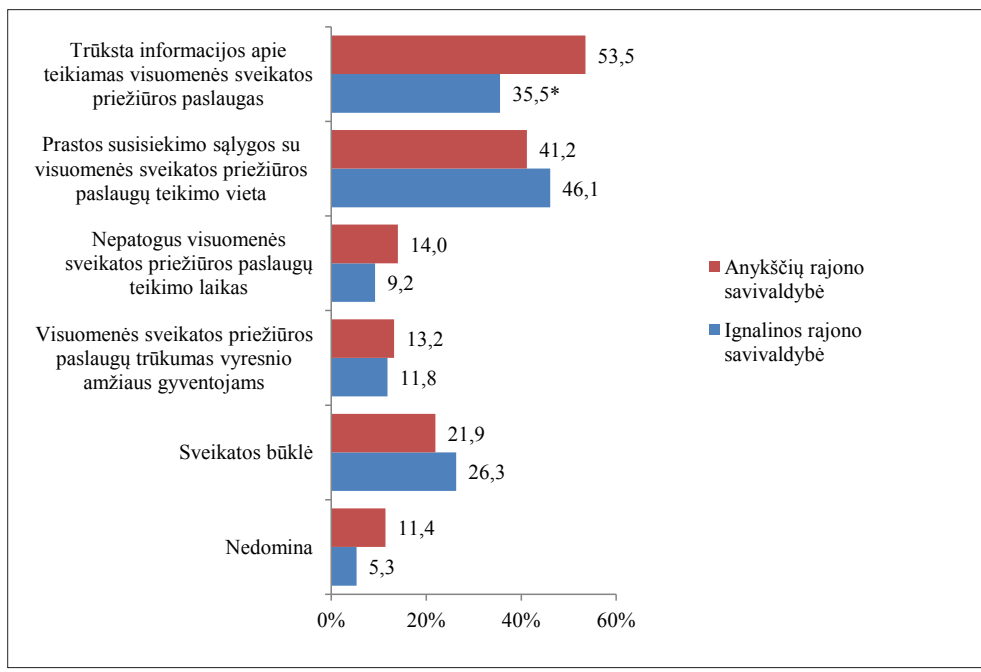

${ }^{*} \mathrm{p}=0,05$, lyginant su Anykščių rajono savivaldybe

2 pav. Vyresnio amžiaus gyventojų nesinaudojimo visuomenės sveikatos priežiūros paslaugomis Anykščių ir Ignalinos rajonų savivaldybėse priežastys 
Tyrimo duomenimis, apie pusė (47,7 proc., $\mathrm{n}=73$ ) Anykščių ir Ignalinos rajonų savivaldybių vyresnio amžiaus gyventojų nurodè, kad trūksta paslaugų ligų profilaktikos srityje, o 42,5 proc. $(n=65)$ - paslaugų sveikatos stiprinimo srityje. Trečdalis $(33,3$ proc., $\mathrm{n}=51)$ vyresnio amžiaus gyventojų teigè, kad stinga sveikos gyvensenos ịgūdžių formavimo renginių, o ketvirtadalis (25,5 proc. $(\mathrm{n}=39)$ - gyvensenos ir/ar elgesio keitimo intervencijų. Abiejų savivaldybių vyresnio amžiaus gyventojai rečiau nurodè, kad trūksta mokymų (19,6 proc., $\mathrm{n}=30$ ) ir konsultacijų sveikatos stiprinimo bei išsaugojimo klausimais 17,6 proc., $\mathrm{n}=27$ ), informacijos apie sveikatą ir jos stiprinimą teikimo paslaugu (17,0 proc., $\mathrm{n}=26)$. Maža dalis (2,0 proc., $\mathrm{n}=3$ ) vyresnio amžiaus gyventojų neturèjo nuomonès dèl visuomenès sveikatos paslaugų stokos savivaldybėse. Anykščių ir Ignalinos rajonų savivaldybių vyresnio amžiaus gyventojų nuomonès dèl visuomenès sveikatos paslaugų nesiskyrè, išskyrus dèl paslaugų sveikatos stiprinimo srityje. Trečdalis (32,8 proc., $\mathrm{n}=21)$ Anykščių ir apie pusė $(49,4$ proc., $\mathrm{n}=44)$ Ignalinos rajonų savivaldybių vyresnio amžiaus gyventojų nurodé, kad jiems trūksta sveikatos stiprinimo paslaugų $(\mathrm{p}=0,040)$.

\section{Rezultatų aptarimas}

Visuomenès sveikatos priežiūros paslaugų prieinamumo analizė Anykščių ir Ignalinos rajonų savivaldybėse leido įžvelgti visuomenès sveikatos politikos igyvendinimo aktualijas. Visuomenès sveikatos priežiūros paslaugomis per pastaruosius metus rečiau naudojosi vyresnio amžiaus gyventojai Anykščių rajono savivaldybeje, sudariusioje bendradarbiavimo sutartị dèl visuomenès sveikatos paslaugų teikimo su Ignalinos rajono savivaldybe, kurioje įsteigtas visuomenès sveikatos biuras. Tyrimo duomenys leidžia teigti, kad abiejose savivaldybèse sprendžiamos visuomenės sveikatos problemos teikiant tokias pačias visuomenès sveikatos priežiūros paslaugas, nes gyventojų naudojimasis daugeliu analizuotų visuomenès sveikatos priežiūros paslaugų nesiskyrè. Remiantis tyrimo duomenimis, Anykščiu ir Ignalinos rajonų savivaldybių vyresnio amžiaus gyventojams dažniau teikiamos informavimo paslaugos apie sveikatą ir jos stiprinimą, tuo tarpu jie retai dalyvavo mokymuose sveikatos stiprinimo ir išsaugojimo klausimais, sveikos gyvensenos igūdžių formavimo renginiuose, ypač gyvensenos ar elgesio keitimo intervencijose. Kiti tyrèjai, analizavę šalies gyventojų visuomenès sveikatos paslaugų prieinamumą, nurodo, kad vyresnio amžiaus gyventojams teikiamos sveikatos stiprinimo paslaugos (pavyzdžiui, sveikos mitybos ir nutukimo prevencijos klausimais), tačiau itin prastas psichikos sveikatos paslaugų prieinamumas ${ }^{15}$. Be to, šio amžiaus gyventojams visuomenès sveikatos paslaugas teike ir nevyriausybinés organizacijos ${ }^{16}$. Sveikatos stiprinimo veiksmai

15 Sveikatos mokymo ir ligų prevencijos centras, supra note 9, p. 110.

16 Ibid., p. 110. 
ir ligų prevencija, bendradarbiaujant ịvairiems sektoriams, įvardijami sveiko senejimo politikos igyvendinimo dalimi ${ }^{17}$.

Tyrime išryškejjo šeimos gydytojo lyderystė teikiant visuomenès sveikatos paslaugas. Tyrimo duomenys papildo kito šalyje atlikto tyrimo duomenis, kad šalies gyventojai, tarp jų ir vyresnio amžiaus, linkę naudotis visuomenès sveikatos priežiūros paslaugomis, kurias teikia sveikatos priežiūros specialistai pirminejje sveikatos priežiūros grandyje ${ }^{18}$. Ši sveikatos priežiūros grandis orientuota ị asmens ir vietos bendruomenès sveikatos problemų sprendimą, teikiant sveikatos stiprinimo paslaugas ${ }^{19}$. Lietuvoje, kaip ir kitose šalyse, susiduriama su visuomenès sveikatos priežiūros paslaugų integravimo pirminès sveikatos priežiūros grandyje iššūkiais ${ }^{20}$. Pagrindine problema išlieka pirminès sveikatos priežiūros ir visuomenès sveikatos priežiūros sektorių bendradarbiavimo stoka. Atsižvelgiant ¡̇ šalies gyventojų senėjimo procesus, vykdant sveikatos reformą tampa aktualu diegti lètinių neinfekcinių ligų valdymo modelius, integruojančius visuomenès sveikatos priežiūros ir pirminès sveikatos priežiūros paslaugas.

Vyresnio amžiaus gyventojų informuotumas apie visuomenès sveikatos priežiūros paslaugas gali būti laikomas svarbiu požymiu, kuriuo remiantis sprendžiama apie jų naudojimąsi visuomenès sveikatos priežiūros paslaugomis. Anykščių ir Ignalinos rajonų savivaldybių vyresnio amžiaus gyventojai, nesinaudoję visuomenès sveikatos paslaugomis, pagrindine nesinaudojimo jomis priežastimi i̇vardijo informacijos apie teikiamas visuomenès sveikatos priežiūros paslaugas stoką. Kito tyrimo duomenimis, gyventojai geriau informuoti apie visuomenès sveikatos biurų veiklą savivaldybèse, kuriose anksčiau buvo ịsteigti visuomenès sveikatos biurai ${ }^{21}$. Nacionalinè sveikatos taryba, LR Seimui atskaitinga sveikatos politikos koordinavimo institucija, atkreipusi dèmesị $\mathfrak{x}$ efektyvesnę institucijų veiklą sveikos gyvensenos srityje, pabrèžè aktyvios informacijos skaidos, gyventojų informuotumo apie sveikatos stiprinimo priemones, pasitelkiant žiniasklaidą bei kitus informacijos sklaidos būdus, svarbą ${ }^{22}$.

Vyresnio amžiaus gyventojai, ypač Anykščių rajono savivaldybëje, linkę patenkinamai vertinti gautas visuomenès sveikatos priežiūros paslaugas. Nors vyresnio amžiaus gyventojų vertinimo motyvai nebuvo analizuojami, tačiau ty-

17 Council of the European Union. Council conclusions of 7 December 2012 on Healthy Ageing across the Lifecycle. Official Journal of the European Union. 2012, C 396/02.

18 Sveikatos mokymo ir ligu prevencijos centras, opt cit., p. 34, 110.

19 Petronytė, G.; Kanapeckienė, V. Pirminès sveikatos priežiūros ir visuomenès sveikatos paslaugu integravimas ir šalių patirtis. Visuomenés sveikata. 2014, 2(65): 20-28.

20 Petronyte, G.; Kanapeckienė, V., supra note 19, p. 20-28.

${ }_{21}$ Jurkuvènas V.; Povilanskienè R. Valstybinès visuomenès sveikatos priežiūros plètros savivaldybèse 2007-2010 metu programos vertinimas. Vilnius: Higienos institutas, 2014, p. 67.

22 Nacionalinès sveikatos tarybos $2012 \mathrm{~m}$. balandžio $10 \mathrm{~d}$. nutarimas Nr. N-2 „Dèl visuomenès gyvensenos ir elgesio keitimo, motyvacijos sveikai gyvensenai didinimo" [interaktyvus]. [žiūrèta 2014-07-25]. <www3.lrs.lt/docs2/KINSPQDY.DOC>. 
rimo duomenys leidžia teigti apie visuomenès sveikatos paslaugų organizavimo problemines sritis. Remiantis tyrimo rezultatais, vyresnio amžiaus gyventojų naudojimasis visuomenès sveikatos priežiūros paslaugomis paaiškinamas šių paslaugų komunikaciniu, organizaciniu ir ekonominiu prieinamumu. Anykščiu rajono savivaldybės vyresnio amžiaus gyventojai lyginant su Ignalinos rajono savivaldybe dažniau susiduria su prieinamumo kliūtimis. Be to, dauguma abiejų savivaldybių vyresnio amžiaus gyventojai įvardino, kad jiems trūksta paslaugų ligų profilaktikos ir sveikatos stiprinimo srityse. Pažymėtina, kad vietos valdžios institucijos vis dar skiria nepakankamai dėmesio sveikatos stiprinimo ir ligu prevencijos klausimų sprendimui ${ }^{23}$.

Nors visuomenès sveikatos biurai igyvendina visuomenès sveikatos politiką savivaldybės lygiu, tačiau juose dirbančių visuomenės sveikatos specialistų lyderystė stebima tik kai kuriose veiklos srityse ${ }^{24}$. Visuomenès sveikatos specialistai neaktyviai dalyvauja visuomenès sveikatos politikos formavimo procesuose ${ }^{25}$, jiems trūksta žinių iggvendinant visuomenès sveikatos politiką ${ }^{26}$, be to, stinga bendradarbiavimo su kitomis institucijomis ir tarpsektorinès veiklos koordinavimo ${ }^{27}$. Savivaldybės lygiu sprendžiant visuomenès sveikatos klausimus tampa aktualu isitraukti ir bendradarbiauti visoms suinteresuotoms institucijoms: vietos valdžiai, visuomenès sveikatos paslaugų teikejjams (visuomenès sveikatos biurams) ir jų gavejjams (gyventojams), taip pat bendruomenèms, visuomeninèms organizacijoms.

Šis tyrimas išryškino vyresnio amžiaus gyventojų naudojimosi visuomenès sveikatos priežiūros paslaugomis skirtumus, kurie didina sveikatos netolygumus. Nacionaliniu lygiu sveikatos politikai prièmé politinius sprendimus ir èmèsi veiksmų, mažinančių sveikatos netolygumus, ypatingą dèmesị skiriant tikslinių teritorijų gyventojų sveikatos priežiūros paslaugų, tarp jų sveikatos stiprinimo ir ligu prevencijos, prieinamumo gerinimui ${ }^{28}$.

23 Nacionalinès sveikatos tarybos 2013 m. lapkričio 26 d. nutarimas Nr. N-5 „Dèl modernios visuomenès sveikatos sampratos ugdymo" [interaktyvus]. [žiūrèta 2014-07-25]. <www3.lrs.lt/ docs2/VEJDKCWU.DOC>.

24 Nacionalinès sveikatos tarybos $2012 \mathrm{~m}$. birželio 27 d. nutarimas Nr. N-4 „Dèl visuomenès sveikatos specialistų lyderystès sveikatos ugdymo ir stiprinimo procese" [interaktyvus]. [žiūrèta 201407-25]. <www3.lrs.lt/docs2/PSJPFQVT.DOC>.

25 Nacionalinès sveikatos tarybos $2012 \mathrm{~m}$. birželio $27 \mathrm{~d}$. nutarimas Nr. N-4, op. cit.

26 Jonušaitè, A.; Čiaplinskienė I. Visuomenès sveikatos biuruose dirbančių specialistų visuomenès sveikatos politikos žinių vertinimas ir tobulinimo poreikis. Sveikatos politika ir valdymas. 2012, 1(4): 185-196.

27 Nacionalinès sveikatos tarybos $2012 \mathrm{~m}$. birželio $27 \mathrm{~d}$. nutarimas Nr. N-4, op. cit.

28 Lietuvos Respublikos sveikatos apsaugos ministro $2014 \mathrm{~m}$. liepos 16 d. ịsakymas Nr. V-815 „Dèl sveikatos netolygumų mažinimo Lietuvoje 2014-2023 m. veiksmų plano patvirtinimo“. Teisès aktų registras [interaktyvus]. [žiūrèta 2014-08-10]. <https://www.e-tar.lt/portal/legalAct.html?d ocumentId=682b6f200d7111e4adf3c8c5d7681e73 > . 


\section{Išvados}

Visuomenès sveikatos priežiūros paslaugomis per pastaruosius metus (12 mèn.) rečiau naudojosi Anykščiu (36,0 proc.) nei Ignalinos (53,9 proc.) rajono savivaldybės vyresnio amžiaus gyventojai $(p=0,001)$. Naudojimasis analizuotomis visuomenès sveikatos priežiūros paslaugomis tarp savivaldybių nesiskyré, tačiau konsultacinès paslaugos sveikatos stiprinimo ir išsaugojimo klausimais dažniau buvo teikiamos Anykščių (37,5 proc.) nei Ignalinos (15,7 proc.) rajono savivaldybės vyresnio amžiaus gyventojams $(\mathrm{p}=0,002)$. Abiejų savivaldybių vyresnio amžiaus gyventojams trūko paslaugų ligų profilaktikos (47,7 proc.) ir sveikatos stiprinimo (42,5 proc.) srityse. Dauguma (83,7 proc.) Anykščių ir Ignalinos rajono savivaldybės vyresnio amžiaus gyventojų pagrindiniu visuomenès sveikatos priežiūros paslaugų teikeju ịvardijo šeimos gydytoją ir/ar slaugytoją.

Ignalinos rajono vyresnio amžiaus gyventojų komunikacinis ir organizacinis visuomenès sveikatos priežiūros paslaugų prieinamumas geras. Anykščių rajono savivaldybės gyventojų visuomenès sveikatos priežiūros paslaugų prieinamumą ribojo komunikacinès ir organizacinès kliūtys: atstumas ir sugaištas laikas iki visuomenès sveikatos priežiūros paslaugų teikimo vietos, visuomenès sveikatos priežiūros paslaugų teikimo laikas. Abiejų savivaldybių vyresnio amžiaus gyventojai naudodamiesi visuomenès sveikatos paslaugomis susidūrè su finansiniais sunkumais dèl transporto išlaidų ir visuomenès sveikatos priežiūros paslaugų stoka.

64,0 proc. Anykščiu ir 46,1 proc. Ignalinos rajono savivaldybès vyresnio amžiaus gyventojų nesinaudojo visuomenès sveikatos priežiūros paslaugomis per pastaruosius metus (12 mèn.). Jie pagrindinèmis visuomenès sveikatos priežiūros nesinaudojimo priežastimis įvardijo informacijos apie visuomenès sveikatos priežiūros paslaugas trūkumą ( 46,3 proc.) ir prastas susisiekimo sąlygas ( 43,2 proc.). Anykščių rajono savivaldybės vyresnio amžiaus gyventojai ( 53,5 proc.) dažniau nei Ignalinos rajono savivaldybès ( 35,5 proc.) nurodè informacijos apie visuomenès sveikatos priežiūros paslaugas trūkumą $(\mathrm{p}=0,015)$.

\section{Rekomendacijos}

Diegti organizuotas vyresnio amžiaus gyventojų informavimo apie visuomenès sveikatos priežiūros paslaugas ir jų teikimą priemones, skelbiant informaciją atsakingų institucijų internetinių tinklalapių specialiose skiltyse, vietinėje spaudoje, žiniasklaidoje, informaciniuose leidiniuose, asmeniškai kviečiant telefonu ar elektroniniu paštu.

Atsižvelgiant $\mathfrak{i}$ konkrečios savivaldybès gyventojų prioritetines sveikatos problemas, diegti inovatyvius sveikatos priežiūros modelius, integruojančius 
pirminès sveikatos priežiūros ir visuomenès sveikatos priežiūros paslaugas, ịtraukiant suinteresuotas institucijas.

Užtikrinti tolygų visuomenès sveikatos biurų finansavimą, parengiant poịstatyminius teisès aktus, siekiant igyvendinti valstybės savivaldybėms perduotas visuomenès sveikatos priežiūros funkcijas.

Skatinant sveiką senèjimą plèsti visuomenès sveikatos priežiūros paslaugų ¿̇vairovę vyresnio amžiaus gyventojams, taip pat bendradarbiauti su pensininkų sąjungos bendrijomis, senelių globos namais ir kitomis institucijomis, ịtraukiant vyresnio amžiaus gyventojus ị sveikatos problemų sprendimą, nustatant jų visuomenės sveikatos priežiūros paslaugų poreikị ir teikimą.

Padèka. Straipsnio autorès dèkoja Ignalinos rajono savivaldybès visuomenès sveikatos biurui, Danutei Gražienei, Rimai Grušnienei ir Onai Vinklerienei už bendradarbiavima ir pagalba atliekant tyrima.

\section{Literatūra}

1. Anykščių rajono savivaldybès tarybos $2012 \mathrm{~m}$. gruodžio 20 d. sprendimas Nr. TS404 „Dèl pritarimo bendradarbiavimo sutarčiai dèl visuomenès sveikatos priežiūros paslaugų teikimo Anykščių rajono savivaldybèje" [interaktyvus]. [žiūrèta 2014-0725]. $<$ http://denver.infolex.lt/anyksciai/Default.aspx?Id=3\&DocId=5246>.

2. Communication from the Commission to the Council, the the European Parliament, the Economic and Social Committee and the Committee of the Regions of 5 December 2001 - The future of health care and care systems for the elderly: guaranteeing accessibility, quality and financial viability. COM/2001/0723.

3. Communication from the Commission to the European Parliament, The Council, The European Economic and Social Committee of the Regions - Dealing with the impact of an ageing population in the EU (2009 ageing raport). COM/2009/180.

4. Council of the European Union. Council conclusions of 7 December 2012 on Healthy Ageing across the Lifecycle. Official Journal of the European Union. 2012, C 396/02.

5. Creative Research Systems [interaktyvus]. [žiūrèta 2013-06-04]. <http://www. surveysystem.com/sscalc.htm>.

6. Decision No 940/2011/EU of the European Parliament and the Council of 14 September 2011 on the European Year for Active Ageing and Solidarity between Generations (2012). Official Journal of the European Union. 2011, L246/5.

7. Ignalinos rajono savivaldybès $2008 \mathrm{~m}$. vasario $14 \mathrm{~d}$. sprendimas Nr. T-224 „Dèl Ignalinos rajono savivaldybès visuomenès sveikatos biuro įsteigimo ir jo nuostatų patvirtinimo" [interaktyvus]. [žiūrèta 2014-07-25]. <http://195.182.92.232/vaktai/ Default.aspx?Id $=3 \&$ DocId $=10280>$.

8. Jurkuvėnas, V.; Povilanskienè, R. Valstybinès visuomenés sveikatos priežiūros plètros savivaldybese 2007-2010 metu programos vertinimas. Vilnius: Higienos institutas, 2014, p. 67. 
9. Jonušaitė, A; Čiaplinskienė, I. Visuomenès sveikatos biuruose dirbančių specialistų visuomenès sveikatos politikos žinių vertinimas ir tobulinimo poreikis. Sveikatos politika ir valdymas. 2012, 1(4): 185-196.

10. Lietuvos Respublikos socialinès apsaugos ir darbo ministro $2012 \mathrm{~m}$. kovo $15 \mathrm{~d}$. įsakymas Nr. A1-156 „Dèl nacionalinès 2012-ųjų Europos vyresnio amžiaus žmonių aktyvumo ir kartų solidarumo metų programos patvirtinimo“. Valstybès žinios. 2012, Nr. 34-1678.

11. Lietuvos Respublikos sveikatos apsaugos ministro $2008 \mathrm{~m}$. kovo $15 \mathrm{~d}$. ísakymas Nr. V-196 „Dèl savivaldybès visuomenès sveikatos biuro pavyzdinių nuostatu patvirtinimo“. Valstybès žinios. 2008, Nr. 35-1253.

12. Lietuvos Respublikos sveikatos apsaugos ministro $2014 \mathrm{~m}$. liepos $16 \mathrm{~d}$. ìsakymas Nr. V-815 „Dèl sveikatos netolygumų mažinimo Lietuvoje 2014-2023 m. veiksmų plano patvirtinimo“. Teisès aktų registras [interaktyvus]. [žiūrèta 2014-08-10]. $<$ https://www.e-tar.lt/portal/legalAct.html?documentId=682b6f200d7111e4adf3c8c 5d7681e73>.

13. Lietuvos Respublikos Vyriausybès 2009 m. vasario 18 d. nutarimas Nr. 111 „Dèl Lietuvos nacionalinès visuomenès sveikatos priežiūros 2006-2013 m. strategijos igyvendinimo priemonių 2009-2013 m. plano patvirtinimo“. Valstybés žinios. 2009, Nr. 22-854.

14. Lietuvos statistikos departamentas [interaktyvus]. Gyventojų skaičius metų pražioje. Požymiai: administracinė teritorija, amžius, lytis [interaktyvus]. [žiūrèta 2013-0604]. <http://db1.stat.gov.lt/statbank/SelectVarVal/Define.asp?Maintable=M3010202\& PLanguage $=0>$.

15. Nacionalinès sveikatos tarybos $2012 \mathrm{~m}$. balandžio 10 d. nutarimas Nr. N-2 „Dèl visuomenės gyvensenos ir elgesio keitimo, motyvacijos sveikai gyvensenai didinimo“ [interaktyvus]. [žiūrèta 2014-07-25]. <www3.lrs.lt/docs2/KINSPQDY.DOC>.

16. Nacionalinès sveikatos tarybos $2012 \mathrm{~m}$. birželio $27 \mathrm{~d}$. nutarimas Nr. N-4 „Dèl visuomenès sveikatos specialistų lyderystès sveikatos ugdymo ir stiprinimo procese“ [interaktyvus]. [žiūrèta 2014-07-25]. <www3.lrs.lt/docs2/PSJPFQVT.DOC>.

17. Nacionalinès sveikatos tarybos 2013 m. lapkričio 26 d. nutarimas Nr. N-5 „Dèl modernios visuomenès sveikatos sampratos ugdymo" [interaktyvus]. [žiūrèta 201407-25]. <www3.lrs.lt/docs2/VEJDKCWU.DOC>.

18. Petronytė, G.; Kanapeckienè, V. Pirminès sveikatos priežiūros ir visuomenès sveikatos paslaugų integravimas ir šalių patirtis. Visuomenés sveikata. 2014, 2(65): 20-28.

19. Sveikatos mokymo ir ligų prevencijos centras. Visuomenès sveikatos priežiūros paslaugų prieinamumo savivaldybėse vertinimas [interaktyvus]. Vilnius, 2012 [interaktyvus]. [žiūrèta 2014-06-25]. <http://www.smlpc.lt/media/file/Programos_ projektai/Tarptautiniai_projektai/1.2.2/IV\%20dalis.pdf $>$.

20. Ščeponavičius, A.; Ašoklienè, L.; Kavaliūnas A. Visuomenės sveikatos priežiūros plètra savivaldybèse. Nacionalinès sveikatos tarybos metinis pranešimas. 2010, p. 65-69.

21. Tarvydienè, N.; Pačiauskienè, I. Visuomenès sveikatos biurų veikla, patirtis, užtikrinant sveiką senejjimą. Nacionalinès sveikatos tarybos metinis pranešimas. 2012, p. $84-86$. 


\title{
Access to Public Health Care Services in Two Municipalities
}

\author{
Agnẻ Pačekaitė, Gintarẻ Petronytė \\ Mykolas Romeris University, Lithuania
}

Summary. This article focuses on access to public health care services for older persons between the municipality that has established the public health bureau and the municipality that has signed an agreement on public health care services provision. The cross sectional survey of 178 older persons of Anykščiai district municipality and 165 older persons of Ignalina district municipality was performed in August - October, 2013. Based on the results, older persons of Anykščiai district municipality used less public health care services over the past year (12 months) than older persons of Ignalina district municipality. There were no differences in using the analyzed public health care services between the municipalities, however, the consulting services in health promotion and maintenance were often provided to older persons of Anykščiai district than Ignalina district municipality. Older persons lacked services for disease prevention and health promotion in both municipalities. Older persons of Ignalina district municipality have good access to public health care services, while access to these services for older persons of Anykščiai district municipality was limited by communication and organizational barriers. Older persons in both municipalities faced with financial difficulties due to transport costs and the lack of public health care services for them.

Keywords: public health care, public health care services, access to public health care services, public health bureau.

Agnė Pačekaitė, Mykolo Romerio universiteto Politikos ir vadybos fakulteto Politikos mokslų instituto magistrè.

Agnè Pačekaitė, postgraduate at Mykolas Romeris University, Faculty of Policy and Management, Institute of Political Science.

Gintarè Petronytė, Mykolo Romerio universiteto Politikos ir vadybos fakulteto Politikos mokslų instituto lektorè, biomedicinos mokslų daktarè.

Gintarè Petronyte், Doctor of biomedicine, lecturer at the Institute of Political Science, Faculty of Policy and Management, Mykolas Romeris University. 